\title{
MOLECULAR CLONING AND PRODUCTION OF RECOMBINANT PHYTASE FROM BACILLUS SUBTILIS ASUIA243 IN PICHIA PASTORIS
}

\author{
Nor Soleha Mohd dali ${ }^{1}$, TAmrin Nuge ${ }^{1}$, Mohd. Hafidz MaHamad Maifiah ${ }^{1}$, \\ FARIDAH YUSOF ${ }^{1}$, ANIS SHOBIRIN MEOR HUSSIN ${ }^{2}$, ABD-ELAZIEM FAROUK ${ }^{3}$ AND \\ HAMZAH MOHD. SALLEH ${ }^{1}$ \\ ${ }^{1}$ Bioprocess and Molecular Engineering Research Unit, \\ Department of Biotechnology Engineering, International Islamic University Malaysia, \\ Jalan Gombak, 53100 Kuala Lumpur, Malaysia. \\ ${ }^{2}$ Department of Food Technology, Faculty of Science and Food Technology, 43400, \\ University Putra Malaysia, Serdang, Selangor, Malaysia. \\ ${ }^{3}$ Department of Biotechnology, Faculty of Science, Taif University, 21974 Taif, \\ Al-Hawiayah, P. O. Box. 888, Saudi Arabia. \\ hamzah@iium.edu.my
}

\begin{abstract}
Phytase gene obtained from Bacillus subtilis ASUIA243 was cloned into a medium vector and transformed into $E$. coli. Restriction enzyme digestion was conducted to get blunt-ended phytase gene and ligated into the Pichia expression vector, pPICZ $\alpha$ A. The recombinant vector, pPICZ $\alpha$ A-243HPp was then linearized with PmeI and transformed into $P$. pastoris strain X33. Screening for multi copy gene number of transformants was done by re-plating the selected colonies on increasing concentration of zeocin. One positive clone, X243HPp\#2 was then grown in BMGY media as the starting culture, followed by induction in BMMY media for protein expression study. The supernatant was then analysed by SDS-PAGE and Western blot method to check the protein expression.
\end{abstract}

ABSTRAK: Gen fitase yang didapati daripada Bacillus subtilis ASUIA243 diklonkan sebagai vektor perantara dan berubah menjadi E. coli. Sekatan pencernaan enzim dijalankan untuk mendapatkan gen fitase berhujung tumpul dan diligatkan dengan vektor ekspresi Pichia, pPICZ $\alpha$ A. Vektor rekombinan, pPICZ $\alpha$ A-243HPp kemudian dilinearkan dengan PmeI dan berubah menjadi P. pastoris strain X33. Penyaringan untuk nombor gen berbilang salinan yang menjalani transformasi genetik dijalankan dengan menyalur semula koloni terpilih dengan penambahan kepekatan zeocin. Satu klon positif, X243HPp\#2 kemudian dibiarkan hidup dalam perantara BMGY sebagai kultur permulaan, diikuti dengan aruhan dalam perantara BMMY untuk kajian penglahiran protein. Supernatan kemudian dikaji dengan SDS-PAGE dan kaedah sap Western untuk menyemak penglahiran protein.

KEYWORDS: phytase; Bacillus subtilis; Pichia pastoris; gene cloning

\section{INTRODUCTION}

Phytase (myo-inositolhexakiphosphate phosphohydrolase) catalyzes the hydrolysis of phytic acid (the principle storage form of phosphorus in legumes, cereals, oil seeds and nuts) to myo-inositol and inorganic phosphate. Phytic acid is a polyanionic chelating agent that forms complexes with several divalent cations of major nutritional importance such as $\mathrm{Ca}^{2+}, \mathrm{Mg}^{2+}, \mathrm{Zn}^{2+}, \mathrm{Cu}^{2+}, \mathrm{Fe}^{2+}$, and $\mathrm{Mn}^{2+}$ [1]. Therefore, the catalytic activity of phytase on 
phytic acid leads to the loss of ability of phytic acid to chelate metal ions. The animal feeds contain phytic acid which cannot be digested by monogastric animals because they have no or low level of phytase activity in their digestive tracks [2]. Inorganic phosphate is frequently added to their feed to facilitate optimal growth for these animals which leads to stimulation of algal blooms and euthrophication of surface water due to the high content of phytate and inorganic phosphate in the excretion of the animals [3]. Thus, supplementation of animal feeds with phytase increases the bioavailability of phosphorus and reduces the phosphorus pollution in the environment. Thus, the benefits of phytase are two-fold: saving the expensive and non-renewable inorganic phosphorus resource by reducing the need for its inclusion in animal diets and protecting the environment from pollution of excessive manure phosphorus runoff [4].

Recent research has shown that microbial sources are more promising for the production of phytases on a commercial level [5]. Most of the scientific work has been done on those originating from filamentous fungi such as Aspergillus niger [6,7], Rhizopus oligosporus [8] and Cladosporium species [9]. Other than these species, phytase from other microbes such as Escherichia coli [10], Pseudomonas species [11], Klebsiella species [12] and Bacillus species [13] were also identified.

Therefore in this research, a local wild type Bacillus subtilis strain ASUIA243 has been chosen as the source for phytase gene and the gene was cloned in an expression vector with strong promoter, pPICZ $\alpha$ A. The recombinant vector was then transformed in the methylotrophic yeast, Pichia pastoris strain X33 for enzyme production. P. pastoris has been chosen as the production host because of the ability to produce the heterologous protein extracellularly, therefore eliminating the method for cell lysis, and the expressed proteins are generally hyperglycosylated [8].

\section{MATERIALS AND METHODS}

\subsection{Strains, Plasmids and Media}

The wild type Bacillus subtilis ASUIA243 strain was obtained from a previous study [14]. The pPICZ $\alpha$ A vector, $\mathrm{pCR}^{\circledR}$-Blunt II-TOPO ${ }^{\circledR}$ vector, Pichia pastoris strain X33 and One Shot ${ }^{\circledR}$ TOP10 competent cell were purchased from Invitrogen, USA. Low salt LuriaBertani (LB) broth and agar were purchased from Becton, Dickinson and Company, USA. Yeast extract, peptone, dextrose and agar for YPDS, BMGY and BMMY media were purchased from Merck, Germany. Glycerol and methanol were purchased from Merck, Germany. Sorbitol was purchased from MP Biomedicals, France. Yeast Nitrogen Base (YNB) for BMGY and BMMY media was purchased from Laboratorios Conda, Spain.

\subsection{Isolation of Phytase Gene}

The plasmid DNA was isolated from the wild-type B. subtilis ASUIA243 by using QIAprep $^{\circledR}$ Spin Miniprep Kit (Qiagen). The phytase gene was then amplified by Polymerase Chain Reaction (PCR). The oligonucleotide primers were designed based on the $B$. subtilis subsp. subtilis str. 168 complete genome obtained from NCBI database (GenBank accession no. NP_389861.1) The primer sequences are the following:

\section{Bsnf5Pp (forward): 5'-GGTACCATGAAGGTTCCAAAAACAATGCTG-3'}

\section{Bsnr6Pp (reverse) : 5'-TCTAGATAGCCGTCAGAACGGTCT-3'}

The underlined sequences in forward and reverse primers represent restriction enzyme site for $K p n \mathrm{I}$ and $X b a \mathrm{I}$, respectively. 
The reaction mixture contained $10 \mu 1$ of 5x Phusion HF Buffer (Finnzyme), $1 \mu 1$ of each primer, $5 \mu \mathrm{l}$ of plasmid DNA, $1 \mu \mathrm{l}$ of $10 \mathrm{mM}$ dNTPs, and $0.5 \mu \mathrm{l}$ of PFU DNA polymerase (Finnzyme). PCR was conducted at a condition of $98{ }^{\circ} \mathrm{C}$ for 2 minutes, 30 cycles of $98{ }^{\circ} \mathrm{C}$ for 10 seconds, $55^{\circ} \mathrm{C}$ for 10 seconds, and $72{ }^{\circ} \mathrm{C}$ for 10 seconds, followed by $72{ }^{\circ} \mathrm{C}$ for 10 minutes, and hold at $4{ }^{\circ} \mathrm{C}$. Gel electrophoresis was done on the PCR products by using $0.8 \%$ agarose gel followed by gel purification using Gel Extraction Kit (Qiagen).

\subsection{Cloning into pPICZaA Vector and Transformation into $P$. pastoris}

The purified PCR products were cloned into pCR $^{\circledR}$-Blunt II-TOPO ${ }^{\circledR}$ as medium vector and transformed into competent One Shot ${ }^{\circledR}$ TOP10 E. coli according to the manufacturer's instructions. The transformants were plated out onto LB medium containing $50 \mu \mathrm{g} / \mathrm{ml}$ kanamycin and incubated overnight at $37{ }^{\circ} \mathrm{C}$.

Next, single colonies were selected and grown at $250 \mathrm{rpm}$ overnight at $37^{\circ} \mathrm{C}$ in 10 $\mathrm{ml} \mathrm{LB}$ broth containing $50 \mu \mathrm{g} / \mathrm{ml}$ kanamycin. The plasmids were extracted by using QIAprep ${ }^{\circledR}$ Spin Miniprep Kit (Qiagen) and digested with $K p n \mathrm{I}$ and $\mathrm{XbaI}$ at $37^{\circ} \mathrm{C}$ for 2.5 hours. The digestion product, 243HPp was purified by using Gel Extraction Kit (Qiagen).

The purified products were then ligated with expression vector, pPICZ $\alpha \mathrm{A}$ that has been already been digested with the same restriction enzymes. The ligation was conducted at $16{ }^{\circ} \mathrm{C}$ for 16 hours. Ligation product was then transformed into One Shot ${ }^{\circledR}$ TOP10 E. coli and plated on low salt LB medium containing $25 \mu \mathrm{g} / \mathrm{ml}$ zeocin (Invivogen, USA). The plates were incubated at $37{ }^{\circ} \mathrm{C}$ overnight. Single colonies were selected and grown in low salt LB broth containing $25 \mu \mathrm{g} / \mathrm{ml}$ zeocin at $37^{\circ} \mathrm{C}, 250 \mathrm{rpm}$ overnight. The plasmids pPICZ $\alpha$ A-243HPp were extracted by using QIAprep ${ }^{\circledR}$ Spin Miniprep Kit (Qiagen) and digested with $K p n I$ and $X b a$ I to confirm for positive clones. One positive clone, pPICZaA243HPp\#1 was chosen for sequencing analysis.

The recombinant plasmid pPICZ $\alpha$ A-243HPp\#1 was linearized with $P m e I$ at $37^{\circ} \mathrm{C}$ for 2.5 hours and transformed into the Pichia pastoris strain X33 $\left(\mathrm{Mut}^{+}\right)$by chemical transformation according to the manufacturer's instructions. The cells were cultured on YPDS media (1\% yeast extract, $2 \%$ peptone, $2 \%$ dextrose, $2 \%$ agar, $1 \mathrm{M}$ sorbitol) containing $100 \mu \mathrm{g} / \mathrm{ml}$ zeocin at $30{ }^{\circ} \mathrm{C}$ for 3 days.

\subsection{Screening for Multiple Copy of Gene}

The positive colonies were plated again on YPDS agar containing different concentration of zeocin: $100 \mu \mathrm{g} / \mathrm{ml}, 500 \mu \mathrm{g} / \mathrm{ml}$ and $1000 \mu \mathrm{g} / \mathrm{ml}$ to screen for the clone with multiple gene copy number. The resistant colony at $1000 \mu \mathrm{g} / \mathrm{ml}$ was selected and transferred to other fresh agar plates. Colony PCR was conducted for a few selected colonies to determine the stable integration of the gene inside the host.

\subsection{Expression of Recombinant Phytase Gene in $\boldsymbol{P}$. pastoris}

One clone from the multiple gene copy number screening was grown in a $250 \mathrm{ml}$ shake flask containing $25 \mathrm{ml}$ of BMGY media ( $1 \%$ yeast extract, $2 \%$ peptone, $1.34 \%$ YNB, $4 \times 10^{-5} \%$ biotin, $1 \%$ glycerol, $100 \mathrm{mM}$ potassium phosphate $\mathrm{pH} 6.0$ ) at $30^{\circ} \mathrm{C}$ and shaken at $250 \mathrm{rpm}$ until the $\mathrm{OD}_{600 \mathrm{~nm}}$ reached 2.0-6.0 (about 26-30 hours). Cells were harvested by centrifugation at $5000 \mathrm{x} g$ at $4^{\circ} \mathrm{C}$ for 5 minutes. The cells were resuspended to an $\mathrm{OD}_{600 \mathrm{~nm}}$ of 1.0 in $100 \mathrm{ml} \mathrm{BMMY}\left(1 \%\right.$ yeast extract, $2 \%$ peptone, $1.34 \% \mathrm{YNB}, 4 \times 10^{-}$

${ }^{5} \%$ biotin, $0.5 \%$ methanol, $100 \mathrm{mM}$ potassium phosphate $\mathrm{pH} 6.0$ ) at $30{ }^{\circ} \mathrm{C}$ for 4 days followed by induction with $0.5 \%$ methanol for every 24 hours. Samples $(1 \mathrm{ml})$ were taken 
at 24-hour intervals to analyse the protein expression. All these methods followed the manufacturer's instructions (Invitrogen, 2002).

\subsection{Analysis of Expressed Recombinant Protein}

Protein expression was analysed on 12\% SDS polyacrylamide gel [15]. Two sets of gels were prepared where one set was subjected to Coomasie blue staining and the other set was subjected to Western blot analysis. Samples $(20 \mu 1)$ were loaded into each well of the gel.

For Western blot analysis, proteins separated by SDS-PAGE was transferred onto nitrocellulose membrane, blocked and incubated overnight with the primary antibody (1:5000). Afterwards, the membrane was washed with buffer and incubated with the polyclonal goat anti rabbit IgG-alkaline phosphatase conjugate used as the secondary antibody for another six hours. The membrane was incubate in a combination of NBT and BCIP (Bio-Rad Laboratories, USA) for colour development.

\section{RESULTS AND DISCUSSION}

\subsection{Cloning and Transformation into $P$. pastoris Host}

The B. subtilis ASUIA243 phytase gene was successfully amplified by using the designed primers, Bnsf5pp and Bsnr6Pp. The primers were designed in such that the $\mathrm{N}$ terminal of the gene was in frame with the $\alpha$-factor signal sequence and the $\mathrm{C}$-terminal of the gene contained no stop codon to include the $c$-myc epitope and 6x-His tag. From the gel electrophoresis (Fig. 1), the bands were located at approximately 1,149bp which is the size of $B$. subtilis phytase gene according to the original DNA template obtained from the NCBI website.

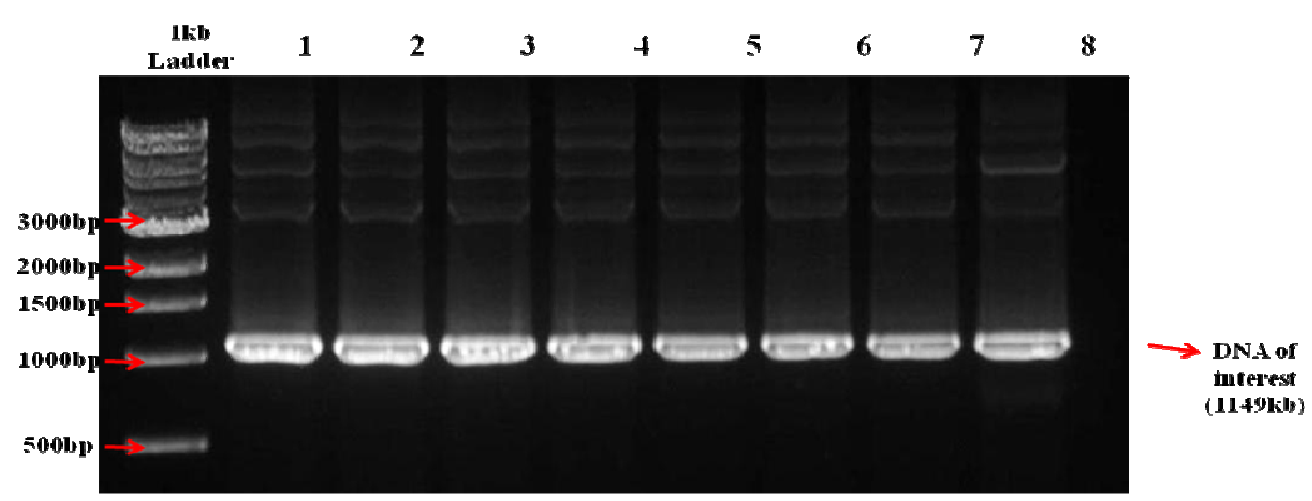

Fig. 1: Gel electrophoresis of B. subtilis ASUIA243 phytase gene by using Bsnf5Pp and Bsnr6Pp primers. The bands are located at approximately 1,149bp.

The phytase gene 243HPp was successfully ligated into the expression vector pPICZ $\alpha \mathrm{A}$ and transformed into the One Shot ${ }^{\circledR}$ TOP10 E. coli in order to get many copies of the recombinant plasmid. Re-screening was done to ensure that the clones were not false positives that caused by nonspecific binding. According to Dale and von Schantz (2002) [16], the re-screening of recombinant colonies is a common practice to pick a recombinant colony that is free from contaminating neighbours. The true positive colonies, pPICZ $\alpha \mathrm{A}-243 \mathrm{HPp}$ were then grown in low salt LB broth, plasmids were extracted and sent for sequencing (Fig. 2). 


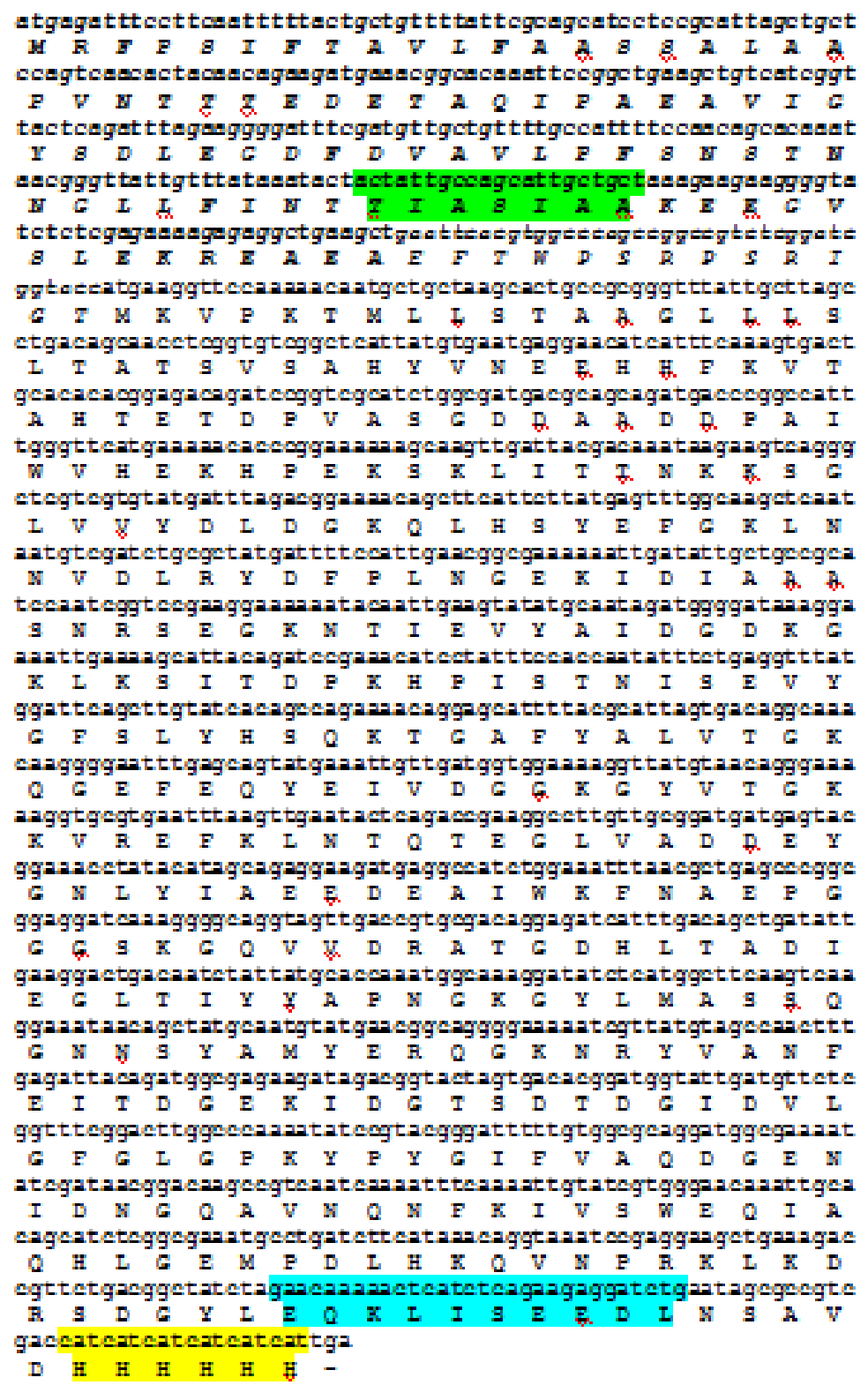

Fig. 2: Sequencing result of pPICZ $\alpha$ A-243HPp shows that the phytase gene is in frame with the $\alpha$-factor signal sequence (italic and green highlighted), $c$-myc epitope (blue highlighted) and the 6x-His tag (yellow highlighted).

The positive recombinant plasmids were linearized with PmeI before being transformed into the $P$. pastoris X33 competent cell. The linear vector DNAs can generate stable transformants of $P$. pastoris via homologous recombination between sequences shared by the vector and host genome [17]. By linearizing the recombinant vector at the unique site located in HIS4 region, Mut+ recombinants were generated [18]. About 38 colonies were selected for multiple gene copy screening, and among these 38 colonies, only 12 colonies contained multiple copy of gene while others were not grown on the $1000 \mu \mathrm{g} / \mathrm{ml}$ Zeocin plate. Colony-PCR was performed on seven of the 12 colonies to determine stable integration of the gene inside the host genome (Fig. 3). One positive clone, X243HPp\#2 was selected for shake-flask expression. 


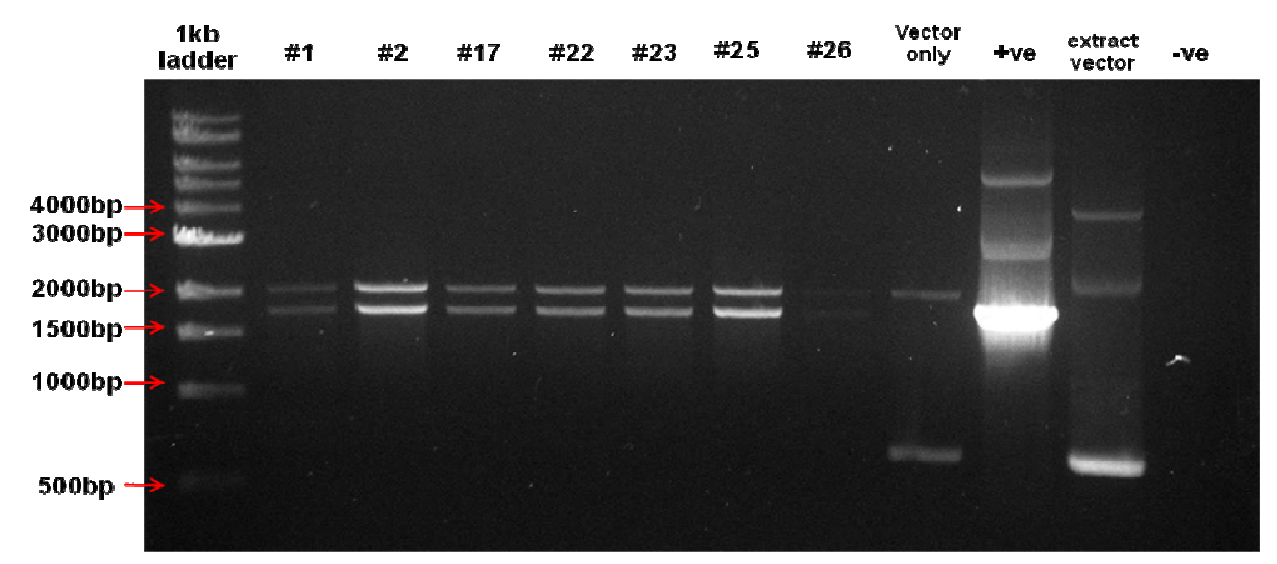

Fig. 3: Gel electrophoresis of colony-PCR. Number \#1, \#2, \#17, \#22, \#23, \#25 and \#26 are the positive colonies from high copy selection.

\begin{abstract}
Vector only is the host with pPICZ $\alpha \mathrm{A}$ only; +ve is the extracted recombinant plasmid with inserted gene; extract vector is the extracted pPICZ $\alpha \mathrm{A}$; -ve is the mixture of PCR reagent with primers only. The result shows that all clones except \#26 have stable integrated gene. The upper bands are located at appr. 2200bp while the lower bands are the inserted genes with parent plasmid PCR products $(1149 \mathrm{bp}+588 \mathrm{bp}=1737 \mathrm{bp})$. For the vector only, the result shows two bands, the upper one is the AOX1 gene (2200bp) and the lower one is the parent plasmid PCR product $(588 \mathrm{bp})$. For $+\mathrm{ve}$, the band indicates the positive result for the gene of interest (1737bp).
\end{abstract}

\title{
3.2 Expression of Recombinant Phytase in $\boldsymbol{P}$. pastoris
}

As shown in Fig. 4, there is no expected band appeared on the SDS-PAGE gel after 4 days of induction. The predicted size of phytase X243HPp\#2 is about $45.02 \mathrm{kDa}$ (including the $c-m y c$ epitope and 6x-His tag). Similarly, no bands were detected on the membrane for Western blot analysis (data now shown). This indicates that no protein was expressed during the induction. However, from the colony-PCR result, we can see that the gene was indeed integrated in the host genome and the DNA sequencing result confirmed that the phytase gene is in frame with the $\alpha$-factor signal sequence, $c$-myc epitope and the $6 \mathrm{x}$-His tag. These results showed that the phytase gene has correctly been inserted into the yeast genome.

Since there was no expressed protein detected on the SDS-PAGE gel and nitrocellulose membrane, there might be a few reasons that would explain this problem. There are many cases of protein expression failure but only fews were reported. Burt et al. [19] explained three main reasons for the lack of expression of biologically active proteins in heterologous system. Host cell lacking components for translation of recombinant protein, the heterologous protein being prone to proteolysis as it emerges from translation, and incomplete or improper folding of heterologous protein can be some of the reasons that lead to the failure of protein expression in heterologous system.

Sreekrishna et al. [20] listed two possible factors which influence protein expression in Pichia systems; untranslated regions in recombinant mRNA, and transcriptional and translational blocks. Since the phytase gene was correctly inserted into the yeast genome, there is also a possibility of excessive transcription. Gasser et al. [21] reported in their work that excessive transcription may cause cellular stress, such that the production rate of polypeptides can be rapid and interfere with correct protein folding. Only properly folded and assembled proteins can be exported within the yeast cell, modified and and 
transported to the extracellular space [22]. Misfolded or aggregated proteins in the cell will be degraded inside the cell [23]. Accumulation of unfolded or misfolded proteins in the cell can also suppresses transcription of the secretory target protein [24].
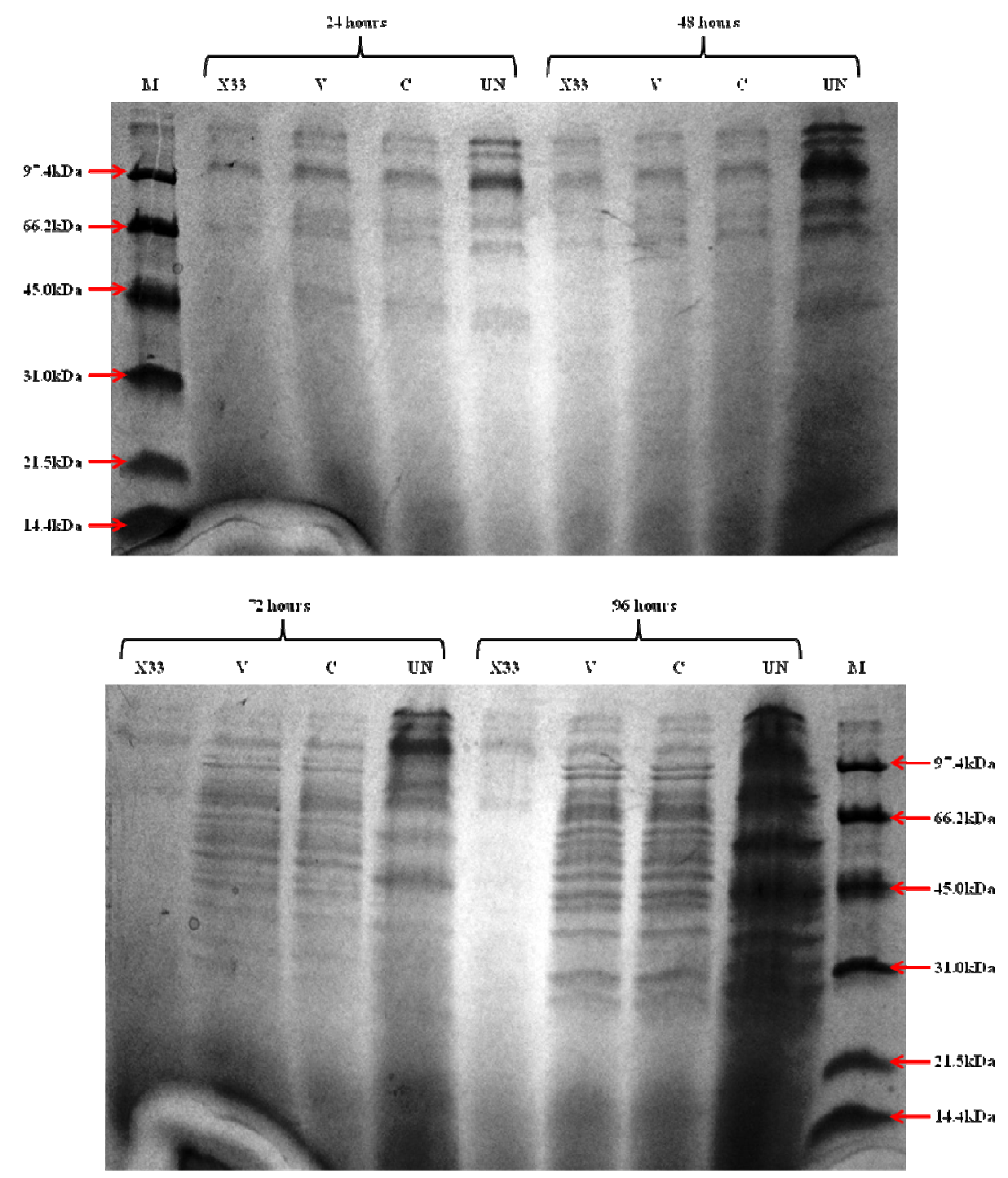

Fig. 4: SDS-PAGE result for induction of phytase X243HPp\#2. X33: Untransformed host cell; V: P. pastoris X33 transformed with pPICZ $\alpha$ A vector only; C: Multiple gene copy clone (X243HPp\#2); UN: clone that was grown in media without methanol inducer; M: protein low range standard marker. There is no expected band appeared on the gel for all four days of induction.

There are many possibilities that can lead to the failure of protein expression in Pichia pastoris. Although only few have been reported, these can be the possible reasons for the problem in this work. Further investigation needs to be conducted. The process conditions and media compositions during the induction time can be other possible reasons for the failure of protein expression and these two conditions should be optimized. Romanos (1995) [25] reported that a critical factor that has long been recognized to affect induction efficiency is aeration of $P$. pastoris culture because in shake-flask inductions, 
the tendency of cultures, especially $\mathrm{Mut}^{+}$strains, to become oxygen-limited is quite high. Besides that, changing the codons in the foreign gene that those of codons more frequently used by the yeast significantly improves the levels of expression of those foreign genes [26]. The A+T ratio of a foreign gene can be changed to one more similiar to the $P$. pastoris genome to improve expression [27].

Changing the expression vector to other alternative vectors is also possible to improve the protein expression. The pPICZ $\alpha \mathrm{A}$ vector contains AOX1 promoter which requires methanol as an inducer. When methanol is oxidized by the alcohol oxidase, the accumulation of the oxidized products, formaldehyde and hydrogen peroxide, can lead to toxicity for the host cell itself, which also can be one of the factors for protein expression failure $[28,29]$. Therefore, changing to other alternative expression vector for protein secretion such as pGAPZ $\alpha$ can be a better solution for this problem. This vector has the glyceraldehyde-3-phosphate $(G A P)$ promoter which does not require methanol for induction, and it is not necessary to shift cultures from one carbon source to another, making strain growth and protein expression more convenient and straightforward [30].

\section{CONCLUSION}

Despite of the problem occurred, $P$. pastoris has become one of the favourite expression systems for the production of various proteins of interest. It is well known that $P$. pastoris secretes very little native protein, providing an advantageous means to recover foreign secreted protein from the supernatant. Other advantages of using $P$. pastoris expression system are ease of fermentation to high cell density, genetic stability and scale up without loss of yield [31], molecular genetic manipulations are simple and protocols are available, can be grown in a simple mineral salts medium [32], high eukaryotic protein modifications such as glycosylation, disulfide-bond formation and proteolytic processing [33].

In this research, the failure of protein expression can be further investigated. It is suggested that the process conditions and media compositions should be optimized to improve the cell growth and protein expression, since the phytase gene was integrated stably in the host genome. The same clone can be used for the optimization or the gene can be re-transformed into a new competent cell. Since there are many reports of successful production of heterologous phytase from various sources using $P$. pastoris expression system, it is possible that our phytase can also be expressed using this expression system after further investigations are conducted.

\section{ACKNOWLEDGEMENT}

This research work is funded by Biotech Research Project from the Ministry of Science, Technology and Innovation (MOSTI) Malaysia, (grant project no. 07-01-08-EIB011). The authors also thanked Dr. Farah Diba Abu Bakar for valuable discussions.

\section{REFERENCES}

[1] Harland, B. F., Oberleas, D. Phytic acid complex in feed ingredients. In: M. B. Coelho, E. T. Kornegay, (eds) Phytase in animal nutrition and waste management. $2^{\text {nd }}$ rev edn. BASF, Mexico, 1999, 69-76.

[2] Schroder, B., Brever, G., Rodehutscord, M. Mechanisms of intestinal phosphorus absorption and availability of dietary phosphorus in pigs. Dtsch Tieraerztl Wochenschr., 1996, 103 : 209-214. 
[3] Oh, B. C., Choi, W. C., Park, S., Kim, Y. O., Oh, T. K. Biochemical properties and substrate specificities of alkaline and histidine acid phytases. Appl Microbiol Biotechnol., 2004, 63, 362-372.

[4] Xin G. L. and Porres, J. M. Phytase enzymology, applications, and biotechnology. Biotechnology Letters, 2003, 25: 1787-1794.

[5] Pandey, A., Szakacs, G., Soccol, C. R., Rodriguez-Leon, J. A., Soccol, V. T. Production, purification and properties of microbial phytases. Bioresource Technology., 2001, 77, 203 214.

[6] Ngo, T. X., Mai, T. H., Vu, N. T. Cloning and over expression of an Aspergillus niger XP phytase gene (phyA) in Pichia pastoris. World Academy of Science, Engineering and Technology, 2009, 56, 750-753.

[7] Soni, S. K., and Khire, J. M. Production and partial characterization of two types of phytase from Aspergillus niger NCIM 563 under submerged fermentation conditions." World J. Microbiol. Biotechnol., 2007, 23, 1585-1593.

[8] Casey, A., Walsh, G. Identification and characterization of a phytase of potential commercial interest. J. Biotechnol., 2004, 110, 313-322.

[9] Quan, C. S., Tian, W. J., Fan, S. D., Kikuchi, Y. I. Purification and properties of a lowmolecular-weight phytase from Cladosporium sp. FP-I.” J. Biosc. Bioeng., 2004, 97, 260266.

[10] Greiner, R., Konietzny, U., Jany, K. D. Purification and characterization of two phytases from Escherichia coli. Arch. Biochem. Biophys., 1993, 303, 117-113.

[11] Cho, J. S., Lee, C. W., Kang, S. H., Lee, J. C., Bok, J. D., Moon, Y. S., Lee, H. G., Kim, S. C., Choi, Y. J. Purification and characterization of a phytase from Pseudomonas syringae MOK1. Curr. Microbiol., 2003, 47, 290-294.

[12] Sajidan, A., Farouk, A., Greiner, R., Jungblut, P., Mueller, E. C., Borriss, R. Molecular and physiological characterization of a 3-phytase from soil bacterium Klebsiella sp. ASR1." Appl. Microbiol. Biotechnol., 2004, 65: 110-118.

[13] Kerovuo, J., Lauraues, M., Nurminen, P., Kalkkinen, N., Apajalahti, J. Isolation, characterization, molecular gene cloning, and sequencing of a novel phytase from Bacillus subtilis. Appl. Environ. Microbiol., 1998, 64, 2079-2085.

[14] Anis Shobirin M. H., Farouk, A., Greiner, R. Potential phytate-degrading enzyme producing bacteria isolated from Malaysian maize plantation. African J. Biol., 2009, Vol. 8, no. 15, 3540-3546.

[15] Laemmli, U. K. Cleavage of structural proteins during the assembly of the head of bacteriphage T4. Nature, 1970, 227, 680-685.

[16] Dale, J. W., and von Schantz, M. From Gene to Genomes: Concepts and Applications of DNA Technology. John Wiley \& Sons Ltd., New York, 2002.

[17] Higgins, D. R. and Cregg, J. M. Pichia Protocols. Humana Press, New Jersey. Vol.10, 1998.

[18] Zou, L., Wang, H., Pan, X., Tian, G., Xie, Z., Wu, Q., Chen, H., Xie, T., and Yang, Z. Expression, purification and characterization of a phyAm-phyCs fusion phytase. Journal of Zhejiang University SCIENCE B, 2008, Vol. 9, No. 7, 536-545.

[19] Burt, T. R., Edavettal, S. C., Hall, J. P. and Mattern, M. R. Sumo fusion technology for difficult-to-express proteins. Protein Expr. Purif., 2005, Vol. 43, No. 1, 1-19.

[20] Sreekrishna, K., Brankamp, R. G., Kropp, K. E. Strategies for optimal synthesis and secretion of heterologous proteins in the methylotrophic yeast Pichia pastoris. Gene, 1997, Vol. 190, No. 1, 55-62.

[21] Gasser, B., Maurer, M., Gach, J., Kunert, R., and Mattanovich, D. Engineering of Pichia pastoris for improved production of antibody fragments." Biotechnol. Bioeng., 2006, 94, 353-361.

[22] Klausner, R. Architectural editing: determining the fate of newly synthesized membrane proteins. New Biol., 1989, 1, 3-8.

[23] Yoshida, H. ER stress and diseases. FEBS Journal, 2007, 274, 630-658.

[24] Schroder, M. and Kaufman, R. J. The mammalian unfolded protein response. Annu. Rev. Biochem., 2005, 74, 739-789. 
[25] Romanos, M. A. Advances in the use of Pichia pastoris for high-level gene expression. Current Opinion in Biotechnology, 1995, 6, 527-533.

[26] Gurkan, C. and Ellar, D. J. Expression of the Bacillus thuringiensis Cy t2Aa1 toxin in Pichia pastoris using a synthetic gene construct." Biotechnol. Appl. Biochem., 2003, 38, 25-33.

[27] Cregg, J. M. Distinctions between Pichia pastoris and other expression system. In Methods in Molecular Biology: Pichia Protocols (ed) Cregg, J. M., Humana Press, New Jersey, p110, 2007.

[28] Couderc, R. and Baratti, J. Oxidation of methanol by the yeast, Pichia pastoris, purification and properties of the alcohol oxidase. Agric. Biol. Chem., 1980, 44, 2279-2289.

[29] Van der Klei, I. J., Bystrykh, L. V., Harder, W. Alcohol oxidase from Hasenula polymorpha CBS4732. Methods Enzymol., 1990, 188, 420-427.

[30] Li, P., Anumanthan, A., Gao, X., Ilangovan, K., Suzara, V. V., Düzgüneş, N., Renugopalakrishnan, V. Expression of recombinant protein in Pichia pastoris. Appl. Biochem. Biotechnol., 2007, 142, 105-124.

[31] Tuite, M. F., Clare, J. J., Romanos, M. A. Expressing cloned genes in the yeasts Saccharomyces cerevisiae and Pichia pastoris." In Protein Expression: A Practical Approach (eds) Higgins, S. J. and Hames, B. D., Oxford University Press, New York, 1999.

[32] Jahic, M., Veide, A., Charoenrat, T., Teeri, T., Enfors, S. Process technology for production and recovery of heterologous proteins in Pichia pastoris. Biotechnol. Prog., 2006, 22, $1465-$ 1473.

[33] Cregg, J. M., Cereghino, L., Shi, J., Higgins, D. R. Recombinant protein expression in Pichia pastoris. Mol. Biotechnol., 2000, 16, 23-52. 